\title{
PENGARUH PEMBERIAN EKSTRAK ETANOL BAWANG TIWAI TERHADAP HISPATOLOGI GINJAL MENCIT
}

\author{
Yurika Sastyarina \\ Fakultas Farmasi Universitas Mulawarman, Samarinda Kalimantan Timur \\ Tel/Fax. : (0541) 73949, \\ email : ureeqa@gmail.com
}

\begin{abstract}
The ethanolic extract from the bulb of Eleutherine americana was investigated for subacute toxicity in Balb/C male mice. The parameter used on this research is kidney histophatological. During subacute toxicity study, bulb plant $(0.52,0,26$ and $5.2 \mathrm{mg} / \mathrm{kg}$ b.wt) p.o. once daily for 30 days. The animals were sacrificed on the $30^{\text {th }}$ day and the kidney were processed for histophatological. The result of descriptive observation histophatological in kidney shows there is inflammation in glomerulus with $2.6 \mathrm{mg} / \mathrm{kg} \mathrm{b.wt} \mathrm{and} 5.2 \mathrm{mg} / \mathrm{kg}$ b.wt dosage. There is oedem in tubulus for dosage given in In tubulus $0.52,0,26$ and $5.2 \mathrm{mg} / \mathrm{kg} \mathrm{b.wt}$
\end{abstract}

Keyword : bulb, Eleutherine americana, histophatological, kidney, mice

\begin{abstract}
ABSTRAK
Telah dilakukan penelitian toksisitas subakut pada ekstrak etanol umbi bawang tiwai (Eleutherine americana (Aubl.). Merr) dari mencit jantan. Parameter yang digunakan dalam penelitian ini adalah hispatologi ginjal. Penelitian ini bertujuan untuk mengetahui gambaran hispatologi dari ginjal yang telah diberi ekstrak etanol bawang tiwai dengan dosis 0,52 $\mathrm{mg} / \mathrm{kgBB}, 2,6 \mathrm{mg} / \mathrm{kgBB}$, dan $5,2 \mathrm{mg} / \mathrm{kgBB}$ pada uji toksisitas subakut dengan pemberian berulang setiap hari sekali selama 30 hari. Hasil pengamatan deskriptif hispatologi terhadap ginjal menunjukkan bahwa pada dosis $0,52 \mathrm{mg} / \mathrm{kgBB}$ terjadi inflamasi pada glomerulus dan pada dosis $2,6 \mathrm{mg} / \mathrm{kgBB}$, dan $5,2 \mathrm{mg} / \mathrm{kgBB}$ terjadi perdarahan. Sedangkan pada dosis 0,52 $\mathrm{mg} / \mathrm{kgBB}, 2,6 \mathrm{mg} / \mathrm{kgBB}$, dan $5,2 \mathrm{mg} / \mathrm{kgBB}$ pada tubulus terjadi oedem.
\end{abstract}

Kata Kunci : Umbi, Eleutherine Americana, hispatologi, ginjal, mencit.

\section{PENDAHULUAN}

Umbi bawang tiwai (Eleutherine americana (Aubl.). Merr) merupakan obat herbal tradisional yang digunakan oleh sebagian masyarakat di daerah Kalimantan dalam bentuk segar. Bawang tiwai ini merupakan sejenis bawang-bawangan, yang tumbuh liar di hutan pedalaman Kalimantan (Mangan, 2005). Efek penggunaan umbi bawang tiwai secara tradisional dan secara ilmiah sudah lama berkembang. Masyarakat suku dayak di daerah Kalimantan mempercayai bawang tiwai sebagai obat untuk revitalisasi tubuh, mengobati luka, dan yang paling besar pengaruhnya yakni sebagai obat anti diabetes. Banyaknya masyarakat yang mengonsumsi secara rutin bawang tiwai per harinya tanpa mengetahui efek apa saja yang ditimbulkan khususnya pada organ manusia dan belum ada penelitian yang menjelaskan lebih rinci tentang efek bawang tiwai terhadap organ jika 
dikonsumsi secara berlebihan. Pada penelitian ini penegasan keamanannya kembali dengan uji toksisitas subakut dan pengamatan pengaruhnya terhadap histologi ginjal hewan uji.

Uji toksisitas subakut sebagai bagian dari uji toksisitas jangka panjang (longterm toxicity) bertujuan untuk mendapatkan data tentang keracunan obat atau bahan (kimia) yang digunakan secara sengaja atau secara tidak sengaja masuk ke dalam tubuh berulang kali, dalam jangka waktu yang lama.

Salah satu organ penting dalam pengamatan toksisitas adalah ginjal. Ginjal merupakan organ yang sangat efisien dalam proses eliminasi zat-zat toksik dari tubuh. Aliran darah ke ginjal yang tinggi dan peningkatan konsentrasi produk yang diekskresi diikuti reabsorpsi air dari cairan tubulus merupakan faktor utama yang terlibat dalam mempengaruhi kepekaan ginjal terhadap zat-zat toksik (Hodgson, E., 2004). Bagian tubulus proksimalis paling mudah mengalami kerusakan akibat ischemia dan zat toksik karena terjadinya proses sekresi dan reabsorbsi sehingga kadar zat toksik lebih tinggi (Lu, 1995). Oleh sebab itu, perlu dilakukan pengamatan perubahan patologi hati dan ginjal akibat pemberian ekstrak etanol bawang tiwai . pada mencit dengan berbagai dosis.

\section{METODE}

\section{a. Bahan}

Bahan yang diteliti pada penelitian ini adalah, umbi bawang tiwai (Eleutherine americana Merr) yang tumbuh di daerah Kadrie Oening Kota Samarinda. Bagian yang digunakan dalam penelitian adalah umbi bawang tiwai yang segar. Kegiatan pada tahap persiapan adalah mempersiapkan umbi bawang tiwai. Sebanyak $2 \mathrm{~kg}$ umbi bawang tiwai segar dipisahkan dari daunnya, dipilih yang tidak lembek. Kemudian umbi bawang tiwai dicuci bersih dengan air, selanjutnya dirajang, dan dikeringkan tanpa terpapar sinar matahari langsung.

\section{a. Ekstraksi}

Selanjutnya sebanyak $766 \mathrm{~g}$ umbi bawang tiwai kering yang telah dirajang, diekstraksi menggunakan metode maserasi, dengan pelarut etanol $96 \%$.. Kemudian ekstrak cair hasil maserasi akan dipekatkan menggunakan rotary evaporator hingga diperoleh ekstrak kental. Sisa pelarut selanjutnya diuapkan di atas water bath untuk memperoleh ekstrak kental pekat $45,74 \mathrm{~g}$.

Selanjutnya dilakukan penyiapan larutan uji. Dosis yang dipakai pada penelitian didasarkan pada dosis lazim standar ekstrak umbi bawang tiwai terhadap mencit yaitu $0,52 \mathrm{mg} / 20 \mathrm{~g} \mathrm{bb}$, yang merupakan dosis rujukan untuk penelitian uji toksisitas pada mencit ini (Sa'roni, dkk., 1990)

\section{c. Penyiapan Hewan Uji}

Tahap ini termasuk kegiatan mempersiapkan 40 ekor mencit jantan dewasa berusia 2 - 3 bulan dengan berat 20-30 gram sebagai objek penelitian. Hewan uji dikelompokkan berdasarkan berat badan. Sebanyak 40 ekor mencit dikondisikan sebaik mungkin dengan ditempatkan pada suhu laboratorium, dan diberi pakan dengan pakan mencit (pellet), serta diberi minum. Mencit yang akan digunakan diadaptasikan dengan lingkungan minimal 1 minggu. Sebelum perlakuan semua mencit ditimbang untuk mengetahui berat badan sehingga mempermudah pengaturan dosis. 


\section{e. Pemilihan Dosis}

Pada tahap pengujian, dosis yang dipakai pada penelitian didasarkan pada dosis lazim standar ekstrak umbi bawang tiwai terhadap tikus yaitu $4,8 \mathrm{mg} / 100 \mathrm{~g} \mathrm{bb}$, yang merupakan dosis rujukan untuk penelitian identifikasi aktivitas ekstrak umbi bawang tiwai dalam menurunkan kadar gula darah (Sa'roni, dkk, 1990).

Sehingga dosis masing - masing kelompok perlakuan pada pengujian ini dapat dilihat pada tabel 1.

Tabel 1. Dosis masing - masing kelompok perlakuan

\begin{tabular}{cc}
\hline Kelompok & Dosis Pemberian \\
\hline Kontrol (-) & Diberi suspensi CMC-Na \\
Perlakuan I & $0,52 \mathrm{mg} / 20 \mathrm{~g} \mathrm{bb}$ \\
Perlakuan II & $2,6 \mathrm{mg} / 20 \mathrm{~g} \mathrm{bb}$ \\
Perlakuan III & $5,2 \mathrm{mg} / 20 \mathrm{~g} \mathrm{bb}$ \\
\hline
\end{tabular}

\section{f. Pembuatan preparat hispatologi dan analisis data}

Setelah pemberian sampel uji selesai, hewan dikorbankan 48 jam setelah pemberian sampel uji kemudian organ ginjal diambil dan dibersihkan. Jaringan kemudian dipreparasi dengan melakukan fiksasi menggunakan neutral buffered formalin dan dibuat sediaan yaitu dengan pewarnaan Hematoxyline Eosin terhadap organ untuk mengetahui keadaan sitologinya serta tingkat kerusakan berdasarkan dari pengamatan pada glomerulus dengan pemberian skor 1 untuk normal, 2 untuk inflamasi dan 3 untuk perdarahan. Pada tubulus pemberian skor 1 untuk normal, 2 untuk oedem, 3 untuk perdarahan dan 4 untuk nekrosis.

\section{HASIL DAN PEMBAHASAN}

Bawang tiwai (Eleutherine americana (Aubl.). Merr) merupakan obat herbal tradisional yang digunakan sebagian masyarakat di daerah Kalimantan dalam bentuk segar. Masyarakat suku dayak lebih mengenal umbi ini dengan sebutan bawang tiwai atau bawang dayak yang selama ini memanfaatkan tanaman ini untuk mengatasi berbagai penyakit salah satunya adalah diabetes (Mangan, 2005). Mengingat penggunaan dimasyarakat dalam bentuk ekstrak air maka perlu dilakukan penelitian untuk menguji keamanan dari suatu bahan salah satunya dengan uji toksisitas.

Toksisitas adalah kemampuan suatu toksikan untuk menimbulkan kerusakan atau kelainan terhadap fungsi suatu sistem biologis. Salah satu bagian uji toksisitas untuk jangka panjang adalah uji toksisitas subakut. bertujuan untuk mendapatkan data tentang keracunan obat atau bahan (kimia) yang digunakan secara sengaja atau secara tidak sengaja masuk ke dalam tubuh berulang kali, dalam jangka waktu yang lama. Apakah obat atau bahan yang diteliti dapat menimbulkan lesi atau cedera pada tubuh, organ apa saja yang rentan dan mudah terkena, bagaimana sifat lesi (reversible ataukah irreversible), dan mulai dosis berapa efek toksik tersebut mulai tampak. Salah satu organ penting dalam pengamatan uji toksisitas adalah ginjal. Ginjal juga menjadi organ utama yang terkena efek toksisitas jika tubuh terpapar zat toksik. Ginjal merupakan organ ekskresi utama yang penting untuk mengeluarkan zat-zat toksik yang masuk kedalam tubuh (Guyton dan Hall, 2007). 
Aliran darah ke ginjal yang tinggi dan peningkatan konsentrasi produk yang diekskresi diikuti reabsorbsi air dari cairan tubulus merupakan faktor utama yang terlibat dalam mempengaruhi kepekaan ginjal terhadap zat-zat toksik (Hudgson dan Levi, 2004). Fungsi utama ginjal adalah mengeluarkan limbah metabolisme, memusnahkan bahan toksik, mengatur cairan, garam, keseimbangan asam basa, serta mengatur tekanan darah (Dellman dan Brown 1992). Selain itu ginjal berfungsi memekatkan toksikan pada filtrat dan membawa toksikan melalui tubulus. Pada perlakuan selama 30 hari didapatkan bahwa kelompok kontrol, tidak ada mencit yang mati; perlakuan dosis $0,52 \mathrm{mg} / \mathrm{Kg} \mathrm{BB}, 5$ mencit yang mati, dosis $2,6 \mathrm{mg} / \mathrm{Kg} \mathrm{BB} 8$ mencit yang mati; dan perlakuan 5,2 $\mathrm{mg} / \mathrm{Kg}$ BB 8 mencit yang mati.

Hasil pemeriksaan histopatologi organ pada hewan uji setelah pemberian peroral ekstrak etanol bawang tiwai berbagai dosis menunjukkan adanya perubahan pada tingkat seluler dari organ ginjal dimana pengamatan dilakukan pada bagian glomerulus dan bagian tubulus yang menunjukkan adanya perubahan antara kelompok kontrol negatif dan kelompok perlakuan. Perubahan yang terjadi meliputi adanya inflamasi, oedem dan perdarahan (gambar 2). Gambar 1 merupakan jaringan ginjal normal. Jaringan ginjal normal dapat dilihat dari keadaan inti sel, keadaan sitoplasma, tidak rusak. Inti sel terlihat berupa titik-titik berwarna biru tua. Glomerulus dan tubulus dalam keadaan normal. Glomerulus yang normal memiliki permeabilitas yang tinggi sehingga tidak mudah dilewati oleh molekul-molekul protein berukuran besar. Selain itu, tekanan osmotik yang cairan intertisium yang rendah menyebabkan hanya sedikit protein yang dapat lolos menembus kapiler. Pada dosis 2,6 mg/Kg BB dan dosis $5,2 \mathrm{mg} / \mathrm{Kg}$ $\mathrm{BB}$ ditemukan perdarahan pada glomerulus (gambar 2). Hal ini merupakan dampak dari kerusakan secara morfologis, yang ditandai dengan terjadinya inflamasi dan diduga terjadi pada peningkatan dosis dari ekstrak bawang tiwai. Menurut Confer dan Panciera (1995), kerusakan yang terjadi sering disebabkan oleh adanya deposisi immun kompleks, trombosis, emboli, dan infeksi virus pada komponen glomerulus. Kerusakan dapat menyebabkan berbagai dampak baik secara morfologi maupun fungsional.. Rusaknya glomerulus secara fungsional ditandai dengan berkurangnya perfusi aliran darah, lolosnya protein dan makromolekul lain dalam jumlah yang besar pada filtrat glomerulus. Kerusakan pada glomerulus juga dapat berupa atrofi dan fibrosis sehingga menyebabkan atrofi sekunder pada tubulus renalis.

Pada tubulus proksimal hanya ditemukan adanya oedem, tidak terdapat perdarahan dan nekrosis sel epitel proksimal sehingga kerusakan yang didapat minimal. Edema terlihat dari perenggangan antar tubulus yang terjadi karena rendahnya tekanan osmotik diluar sel menyebabkan cairan masuk ke dalam sel. Edema intraseluler dapat terjadi pada jaringan yang meradang. Peradangan biasanya mempunyai efek yang langsung pada membran sel yaitu meningkatkan permeabilitas, memungkinkan natrium dan ion-ion lain berdifusi masuk ke dalam sel dengan diikuti osmosis air ke dalam sel. Sel-sel yang mengalami degenerasi berbutir, peradangan, akan mengalami nekrosis (kematian sel) akibat adanya reaksi terhadap zat kimia dalam hal ini zat toksik umbi bawang tiwai. 


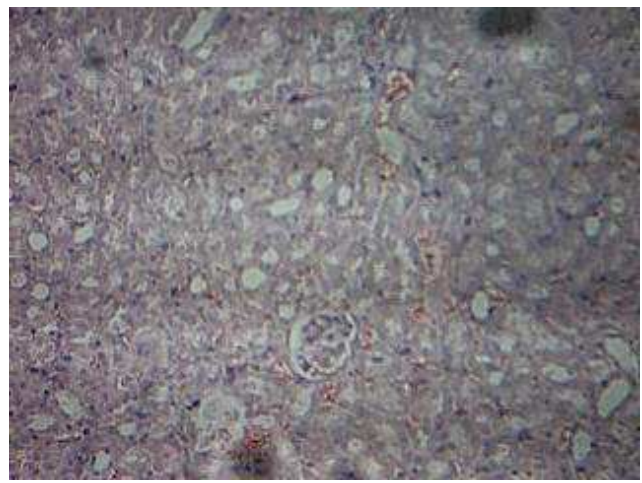

Gambar 1. Hispatologi ginjal normal

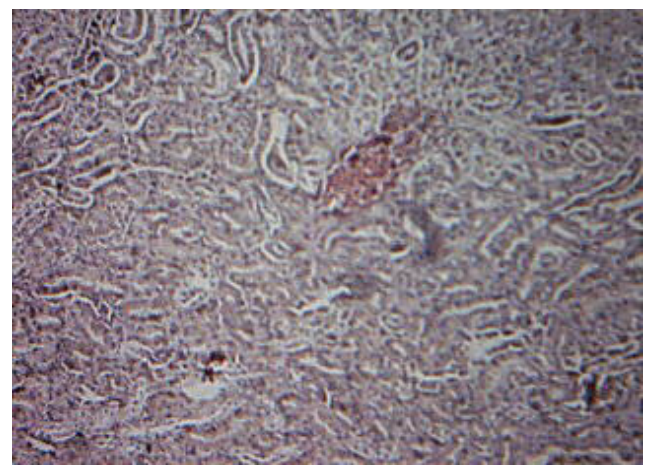

Gambar 2. Hispatologi ginjal yang mengalami inflamasi dan perdarahan

Tabel 2. Perubahan pada glomerulus

\begin{tabular}{|c|c|c|c|c|c|c|c|c|c|c|}
\hline Perlakuan & 1 & 2 & 3 & 4 & 5 & 6 & 7 & 8 & 9 & 10 \\
\hline Kontrol & 0 & 0 & 0 & 0 & 0 & 0 & 0 & 0 & 0 & 0 \\
\hline $1 \mathrm{x}$ dosis & 0 & 0 & 1 & 1 & 1 & & & & & \\
\hline $5 x$ dosis & 0 & 2 & & & & & & & & \\
\hline 10x dosis & 2 & 2 & & & & & & & & \\
\hline
\end{tabular}

Keterangan :

$0=$ normal

$1=$ inflamasi

$2=$ perdarahan

$3=$ nekrotik

Tabel 3. Perubahan pada tubulus

\begin{tabular}{|c|c|c|c|c|c|c|c|c|c|c|}
\hline Perlakuan & 1 & 2 & 3 & 4 & 5 & 6 & 7 & 8 & 9 & 10 \\
\hline Kontrol & 0 & 0 & 0 & 0 & 0 & 0 & 0 & 0 & 0 & 0 \\
\hline $1 \mathrm{x}$ dosis & 0 & 0 & 0 & 1 & 1 & & & & & \\
\hline $5 x$ dosis & 1 & 1 & & & & & & & & \\
\hline 10x dosis & 1 & 1 & & & & & & & & \\
\hline \multicolumn{11}{|l|}{ Keterangan: } \\
\hline \multicolumn{11}{|l|}{$0=$ normal } \\
\hline \\
\hline \multicolumn{11}{|c|}{$\begin{array}{l}1=\text { oedem } \\
2=\text { perdarahan }\end{array}$} \\
\hline \multicolumn{11}{|c|}{$3=$ nekrotik } \\
\hline
\end{tabular}




\section{KESIMPULAN}

a. Ekstrak bawang tiwai (Eleutherine americana (Aubl.). Merr) yang diberikan mencit jantan selama 30 hari pada dosis $0,52 \mathrm{mg} / 20 \quad \mathrm{~g} \quad \mathrm{BB}$ menyebabkan inflamasi pada glomerulus sedangkan dosis $2,6 \mathrm{mg} / 20$ $\mathrm{g} \quad \mathrm{BB}$ dan 5,2 $\mathrm{mg} / 20 \mathrm{~g} \quad \mathrm{BB}$ menyebabkan perdarahan pada glomerulus.

b. Ekstrak bawang tiwai (Eleutherine americana (Aubl.). Merr) yang diberikan mencit jantan selama 30 hari pada dosis 0,52 mg/20 g BB, 2,6 $\mathrm{mg} / 20 \mathrm{~g}$ BB dan $5,2 \mathrm{mg} / 20 \mathrm{~g} \mathrm{BB}$ menyebabkan oedem pada tubulus

\section{UCAPAN TERIMA KASIH}

Terima kasih diucapkan kepada UP Fakultas Farmasi Universitas Mulawarman yang telah membiayai penelitian ini

\section{DAFTAR PUSTAKA}

1. Confer AW dan Panciera RJ. 1995. Thomson's Special Veterinary Pathology. Edisi ke-2. Edited by: Carlton WW dan McGavin MD. Mosby.
2. Cotran RS. Ginjal dan sistem penyalurannya. In: Robbins SL, Kumar V. Staf Pengajar Laboratorium Patologik Anatomik Fakultas Kedokteran Universitas Airlangga, editor. Buku ajar patologi II. 4th ed. Jakarta: EGC, 1995; p. 203-04

3. Hodgson E, Levi PE. Nephrotoxicity. In: Hodgson E, editor. A Textbook of modern toxicology, 3rd ed. New York: John Wiley \& Sons, 2004; p. 273-75.

4. Lu FC. 1995. Toksikologi Dasar. Edisi ke2. UI Press. Jakarta

5. Mangan, Yellia., 2005, Cara Bijak Menaklukan Kanker, Agromedia Pustaka ; Jakarta

6. Price S, Wilson L. 1995, Patofisiologi konsep klinis proses-proses penyakit buku 1, edisi keempat. Jakarta: EGC;

7. Widyati, T.W., 2011, Efek Ekstrak Umbi Bawang Tiwai (Eleutherina americana Merr), Skripsi, Fakultas Farmasi Universitas Mulawarman, tidak dipublikasikan. 